Journal of

Education and Practice (JEP)

TEACHERS' PERCEPTION ON DILAPIDATED SCHOOL STRUCTURES AND THE ACHIEVEMENTS OF PUPILS IN PRIMARY SCHOOLS IN KOGI STATE, NIGERIA

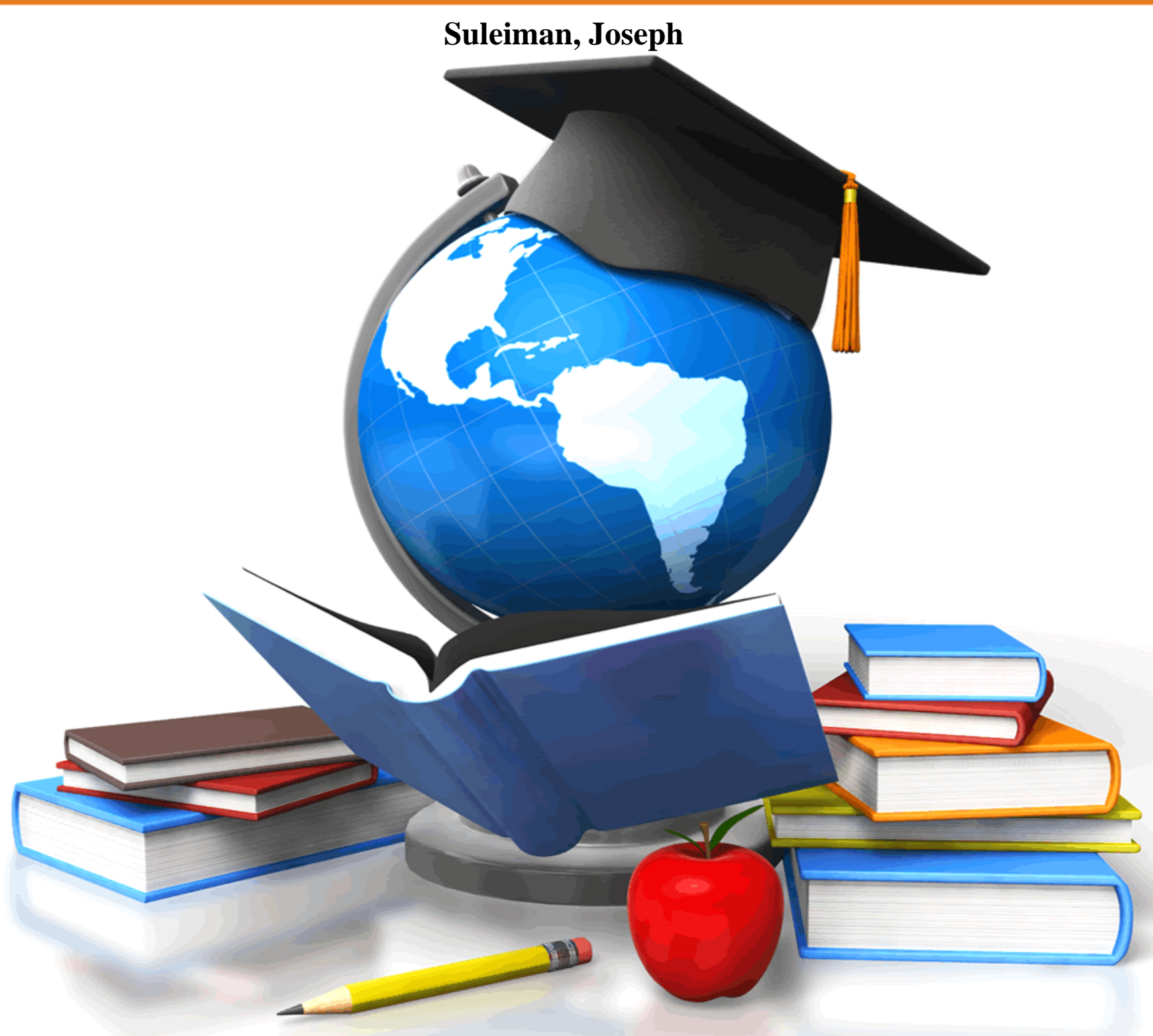

CARI 
Journal of Education and Practice

ISSN 2520-467X (online)

Vol.4, Issue No.4, pp 14 - 42, 2020

www.carijournals.org

\title{
Teachers' Perception on Dilapidated School Structures and The Achievements of Pupils in Primary Schools in Kogi State, Nigeria
}

\author{
${ }^{1 *}$ Suleiman Joseph \\ ${ }^{1}$ Post Graduate Student: General Studies Education Department Federal College of Education \\ Okene, Kogi State, Nigeria \\ *Corresponding Author's Email: josephsuleiman8@gmail.com
}

\begin{abstract}
Purpose: This study investigated teachers' perception on the influence of dilapidated school structures on the academic performance of pupils in primary schools in Kogi State. Seven research questions guided the study which clustered on the state of dilapidation, pupils' achievement and their relationships across the three Senatorial Districts of the State. One research hypothesis was stated for the study to ascertain the significance or otherwise of the relationship between dilapidated school structures and the academic achievement of primary school pupils.
\end{abstract}

Methodology: The qualitative survey design was used for the study and a sample of 1,500 teachers from a total of 6,850 teachers was drawn from the population of all the public primary school teachers through stratified random sampling. Interviews were conducted to support the questionnaire that was the major instrument for the study. Two were designed with nine (9) items to elicit responses on possible indicators of dilapidation of schools and achievement on a scale of Strongly Disagree, Disagree, Agree, and Strongly Agree with arithmetic values of 1, 2, 3 and 4 respectively. The questionnaires were given to one teacher and one head teacher per senatorial district and two experts in measurement and evaluation to ascertain their validity. To test for their reliability, the Cronbach's alpha was used and it yielded coefficients of 0.753 for dilapidation of schools and 0.663 for achievement. The data generated were analysed using Likert scale percentage analysis, correlation, mean score analysis, ranking, excel coding and SPSS. The data collected was also analyzed using Pearson correlation to determine relationships and test the stated hypothesis at 0.05 level of significance.

Results: The study showed that school dilapidation across the three senatorial districts in Kogi State vary, achievement of pupils were not rated high and there is a linear relationship between school dilapidation and school achievement in Kogi State. However, from the tested hypothesis, school dilapidation does not significantly influence school achievement in the state.

Unique contribution to theory, policy and practice: It concluded that if our education must deliver the benefits it holds, then the physical structure of our primary school is a sure area to consider. It recommended among others that Government should ensure that there are sufficient desk in classrooms, repair or replace of bad/damaged seats, avoid the use of buildings with licking class roofs and there should be a declaration of a state of emergency on school system to salvage and surmount the identified challenges.

Key Words: Teachers' Perception, Dilapidation, School Structures, Achievements, Pupils 
Journal of Education and Practice

ISSN 2520-467X (online)

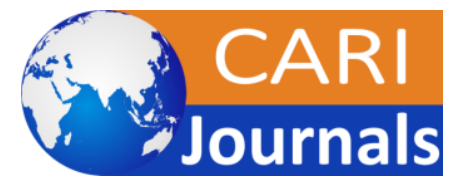

Vol.4, Issue No.4, pp 14 - 42, 2020

www.carijournals.org

\section{INTRODUCTION}

One of the six Education for All (EFA) goals agreed by over 160 governments during the World Education Forum in Dakar in 2000 is the delivery of quality of education to their citizens. Consequent upon this, nations all over the world, including Nigeria made deliberate efforts to provide quality education to achieve the goals of EFA by 2015. United Nations Educational, Scientific and Cultural Organization (UNESCO,2012) observed that in today's world, education systems must constantly evolve in order to effectively respond to the rapidly changing demands of the societies they serve. Thus, the Commissioner of Education of Kogi State, Mrs Elebiyo, G.Y. left no one in doubt about the state's commitment to ensure quality education when she stated that, poor school standards will be history in Kogi State (Naija News, 2013).

All the talk about falling standard in education will continue to worsen until concerted efforts are made to address basic education and in particular, primary education as it is the level that feed the secondary and then tertiary. If the foundation here is weak, the structure that will be built on this may not endure. This stage must be properly taken care of. It could serve as a platform for addressing societal problems such as ignorance, illiteracy, religious violence, insecurity and political servitude. It provides young learners with the fundamentals of reading, writing, skill acquisition, information and attitudes necessary for proper adjustment into the society.

In Nigeria, primary education is the education children receive before secondary education and thereafter the tertiary stage. Consequently, the broad goals of primary education are geared to prepare the individual for useful living within the society and to progress to other higher education (Federal Republic of Nigeria, 2004). Education is an investment and an instrument that can be used to achieve economic, social, political, technical, scientific and cultural development in a country. The role of primary education is to lay a solid foundation for better academic performance of learners in their pursuit of higher education with the aim of producing competent manpower for the growth and development of the nation. The menace of mass failure in the final examinations conducted by various examination bodies West African Examinations Council (WAEC), National Examination Council (NECO), National Business and Technical Examinations Board (NABTEB) has led to calls by all and sundry over students' poor academic performance which is premised on a weak primary education (Okoza, Aluede and Akpaida, 2012).

There is no misgiving that student's high-quality academic performance and outcomes is connected to the nature of learning environment and the available useful facilities. The educational process of development occurs in physical, social, cultural and psychological environment which implies that a proper and adequate environment is very much necessary for a fruitful learning (Mudassir and Norsuhaily, 2015). They added that the educational process of development occurs in physical, social, cultural and psychological environment which implies that a proper and adequate environment is very much necessary for a fruitful learning. According to Oduwaye (2011), learning environment or facility refers to the context in which learning takes place. It is the surrounding circumstance which effects learning. A learning environment is the condition and influence which a learner comes in contact with, resulting in a series of complex interactions and ensuring a permanent change in behaviour. Learning environment is composed of some components that influence the student's learning curve. Mgbodile as cited by Osuji (2016) stressing the need for school facilities, observed that the physical appearance and general condition 
Journal of Education and Practice

ISSN 2520-467X (online)

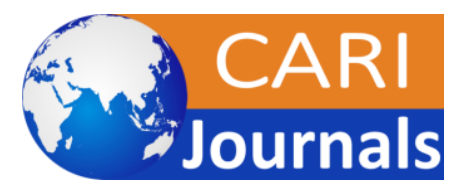

Vol.4, Issue No.4, pp 14 - 42, 2020

www.carijournals.org

of school physical facilities are the striking basis upon which many parents and friends of any educational institutions may make their initial judgments about the quality of what goes on in the school.

Nwagu (2010) states that classrooms constitute the most basic facilities that every school must have. He pointed to the Nigerian situation where many school buildings and facilities have been constructed without enough consideration for the comfort of students' and teachers' who use them. Today, most of the school facilities which are supposed to promote and enhance teaching, learning and extra-curricular activities are obsolete and thereby, creating serious challenges to the $21 \mathrm{st}$ century educational needs of the learners. Others are dilapidated and not suitable to motivate learners. In a study carried out by Hale as cited by Ibitoye (2017), revealed that students in classrooms with large windows, natural lighting and well-designed skylights were found to perform well from $19 \%$ to $25 \%$ better than their peers in classrooms without these feature.

Adamu (2015) examined the impact of environment on the Performance of Students in public secondary schools in Taraba State, Nigeria and the findings revealed a significant difference in the performances of the two groups (Experimental and Control) implying that a classroom building; class with adequate furniture; class with small class population and the use of instructional materials has positive impact on the performance of students in junior Secondary schools.

Unfortunately, some critical stakeholders in education in the South-East and South-South zones have decried the dilapidation of school structures and classrooms, calling for Federal Government's urgent intervention in education sector (Home Latest News, 2018). Similarly, the Northern states have their share of complains in this ugly trend as expressed by Musa as cited in Osuji (2016). They reiterated that the available reports revealed mainly dilapidated structures and not maintained facilities. Today, most of the school facilities in Kogi state which are supposed to promote and enhanced teaching and learning in secondary education are obsolete in form thereby creating a serious challenge to the 21 st century educational needs of the learners.

\section{Statement of the Problem}

The successful implementation of any educational programme depends mostly on the quality of the learning environment that are provided for such programmes. According to an investigation carried out by Emmanuel and Omale (2020) in the state, public schools had been neglected by the state and local governments. They found that there are not enough desks for all the learners and most of the desks were already in bad shape. According to the report, the walls of the classroom buildings were covered with torn election posters, peeled paints and unkempt grasses within the premises. The ceilings of the classrooms were falling off with some parts detached and hanging. However, it was reported by Abdullahi (2019) that the state had embarked on a total renovation of dilapidated structures in public schools, construction of new ones as well as build more classrooms in several schools in order to create a serene and conducive learning environment for pupils in Kogi State.

In spite of the various efforts put by government and stakeholders in this regard, one cannot help but observe the unhealthy nature of most of the buildings, uncompleted, old and antiquated, sometimes unattractive buildings, , insufficient desks, overcrowded and un-conducive, etc in some parts of the state, particularly in the rural areas. In view of this observations, the worry of this study 
Journal of Education and Practice

ISSN 2520-467X (online)

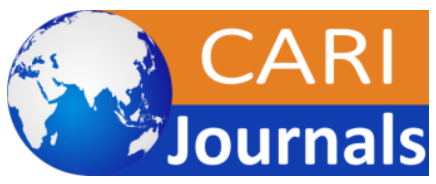

Vol.4, Issue No.4, pp 14 - 42, 2020

www.carijournals.org

was to find out the state of dilapidation of school structures across the state and determine whether school structures influence achievement. Furthermore, the available studies on the subject matter were scarcely conducted in Kogi State. Hence, the scantiness of literature on influence of dilapidated school structures on the academic performance of pupils in Kogi State has created a knowledge gap.It is hoped that the findings of this study may likely contribute significantly to the body of knowledge on the subject matter. Against this background, this study investigated teachers' perception on the influence of dilapidated school structures on the academic performance of pupils in primary schools in Kogi State.

\section{Objective/Purpose of the Study}

The intent of this study was to investigate the influence of school structures on pupils' academic achievement in primary schools in Kogi State, Nigeria. Specifically, the study sought:

i. Determine the extent of dilapidation of schools by teachers' perspective in the three senatorial districts of Kogi State

ii. Find out the level of pupils' achievement by teachers' perspective in the three Senatorial Districts of Kogi State.

iii. Establish the relationship of the state of dilapidation of schools by teachers' perspective for the three Senatorial Districts of Kogi State

iv. Establish the relationship of the state of pupils' achievement in schools by teachers' perspective for the three Senatorial Districts of Kogi State

v. Compare the factor measures of dilapidation within Kogi State

vi. Compare the factor measures of achievement within Kogi State

vii. Find out the relationship between dilapidation of schools and pupils' achievement in Kogi State as perceived by teachers

\section{Research Questions}

The following research questions guided the study:

i. What is the extent of dilapidation of schools by teachers' perspective exist in the three Senatorial Districts of Kogi State?

ii. What is the level of pupils' achievement by teachers' perspective in the three Senatorial Districts of Kogi State?

iii. What relationship exists in the state of dilapidation of schools by teachers' perspective in the three Senatorial Districts of Kogi State?

iv. What relationship exists inthe state of pupils' achievement in schools by teachers' perspective in the three Senatorial Districts of Kogi State?

v. What Comparison exists in the factor measures of dilapidation within Kogi State?

vi. What Comparison exists in the factor measures of achievement within Kogi State?

vii. What is the relationship between dilapidation of schools and pupils' achievement in Kogi State as perceived by teachers? 
Journal of Education and Practice

ISSN 2520-467X (online)

Vol.4, Issue No.4, pp 14 - 42, 2020

www.carijournals.org

\section{Research Hypothesis}

There is no significant relationship between dilapidated school structures and the academic achievement of primary school pupils in Kogi state.

\section{LITERATURE REVIEW}

\section{Theoretical Review}

The basis of this research work can be traced and related to the system theory. A system is a sum total of parts working independently and interdependently to achieve required results or outcomes based on needs Ovwigbo as cited in Osuji (2016). This implies that a collection of people, resources, concepts and procedures intended to perform some identifiable function or to achieve a goal. A system is made up of input, transformation process, and output; meanwhile, these are surrounded by an environment. Musa as cited in Osuji (2016) asserts that system effectiveness refers to the extent to which goals are achieved in the school environment. Therefore, effectiveness is considered to measure the degree of goals attainment of the school of learning.

The system theory considerers a school as a social system which survival depends on the system's ability to maintain the relative consistency of its processes. The theoretical frame work notes that the influence of school facilities on Pupil's performances hold a very important position in any school. The main aim of school facilities is to ensure that students as well as teachers are comfortable to teach and learn in order to achieve a great performance.

\section{Empirical Review}

According to Mitchell as cited by Adamu (2015) the environment in which you study can have a big effect on how efficient your study time is. He identified noise, interruptions, lighting, temperature, neatness, comfort, instructional materials, facilities such buildings and equipment to have potential effect on study habits. In a related development, Mudassir and Norsuhaily, (2015) conducted a study to examine how school environment influence students' academic performance in selected secondary schools within Kuala Terengganu. The result of the study indicated that students from a school with adequate facilities, good teachers and favorable environment perform better than those from schools with fewer facilities, unqualified teachers and less enabling environment. Nwagwu as cited by Adamu (2015) maintained that the quality of education that children receive bears direct relevance to the availability or lack of physical facilities and overall atmosphere in which learning takes place. The fact is if students have motivation in their schools interior environment, they would be more academically successful (Fielding, 2010).

The importance of classroom conditions to a successful academic achievement cannot be overemphasized. The learning environment or facilities includes school location and physical buildings, laboratory equipment, library services and materials, instructional aids and effective classroom management. Facilities could also be explained as the entire school plant such as blocks of classrooms, staffrooms, laboratories, workshops, libraries, laboratory equipment, consumables, audio-visual aids, electricity, water, chairs, tables, stationeries, playground, storage spaces and others which school has. Environmental factors like classrooms, textbooks, equipment, school supplies, and other instructional materials etc. are the physical conditions needed for learning (Mondal, 2012). This shows that, we influence and are influenced by the physical environment 
Journal of Education and Practice

ISSN 2520-467X (online)

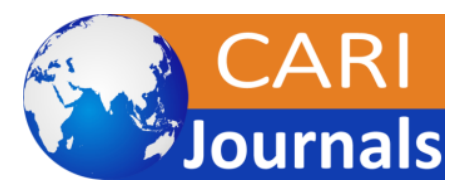

Vol.4, Issue No.4, pp 14 - 42, 2020

Www.carijournals.org

around us. Murugan and Rajoo as cited in Shamaki (2015) submitted that creating an ideal learning environment ought to be a priority of every concerned educationalist because being comfortable should be a combination of several factors which include temperature, lighting, and noise control etc. According to Mitchell as cited by Adamu (2015) the environment in which you study can have a big effect on how efficient your study time is. He identified noise, interruptions, lighting, temperature, neatness, comfort, instructional materials, facilities such buildings and equipment to have potential effect on study habits. Students of a school with adequate facilities, good teachers and favorable environment perform better than those from schools with fewer facilities, unqualified teachers and unfavorable environment (Mudassir and Norsuhaily, 2015)

The Vanguard (2012) reported that, the President of the Nigerian Union of Teachers (NUT), Olukoya, at the Eagle Square in Abuja lamented the deteriorated state of schools at Local Government, State and Federal government levels, regretting the poor condition of the schools and its negative contribution to the performance of pupils and students across the nation. According to him, "we wish to use this auspicious day to remind the government of Nigeria on all the tiers that our schools are still largely dilapidated and are unsuitable for conducive learning". Olukoya noted that, "Learners do well when they study in a conducive environment. It is a conducive environment that makes a teacher to perform at his optimum". Furthermore, Ezike,(2018) investigated classroom environment and students' academic interest as correlates of achievement of students in selected Public Secondary Schools in Ibadan, Oyo State, Nigeria. The result showed significant relationships between classroom environment and academic achievement, while combined contribution of classroom environment and academic interest was equally significant. The physical environment/learning space refers to the physical setting of the learner's environment which should evoke positive responses and hold the interests of those who inhabit it (Balog,2018). This implies that the physical structure of the school building could serve as a motivator or otherwise as regards learners' academic achievement. In response to this, Osun State, no fewer than 3,000 dilapidated school buildings out of the 4,000 identified across the 30 local government area were demolished by the state government. This was disclosed by the Chairman, Osun Schools Infrastructure Development Committee, Chief Lai Oyeduntan in Osogbo (Nigeria Newsday, 2013) in the State's bid to ensure quality education.

Adamu (2015) examined the impact of environment on the Performance of Students in public secondary schools in Taraba State, Nigeria and the findings revealed a significant difference in the performances of the two groups (Experimental and Control) implying that a classroom building; class with adequate furniture; class with small class population has positive impact on the performance of students in junior Secondary schools. In another research by Ezike (2018) investigated classroom environment and students' academic interest as correlates of achievement of students in selected Public Secondary Schools in Ibadan, Oyo State, Nigeria. The result showed significant relationships between classroom environment and academic achievement, while combined contribution of classroom environment and academic interest was equally significant.

Furthermore, Gilavand (2016) in a study whose aim is to investigate the impact of environmental factors (schools' open space, noise, lighting and paintings in educational institutions) on learning and academic achievement of elementary students, found that environmental factors (appropriate coloring, lighting of educational environment and schools' open space) has impact on learning and 
Journal of Education and Practice

ISSN 2520-467X (online)

Vol.4, Issue No.4, pp 14 - 42, 2020

www.carijournals.org

academic achievement of elementary school students. Similarly, Eimuhi and Ogedegbe (2016) in a research titled the effect of environmental factors in teaching and learning in primary and secondary schools in Edo state of Nigeria examined environmental factors to determine the outcome of teaching and learning at all times and in all places and concludes that the more enriched the learning environments is, the greater and more widespread are the benefits for academic performance and other outcomes. These two studies are similar to the present study because they were conducted in elementary and primary school settings. It is important to state here that, empirical studies on the influence of school structures on the performance of pupils were scarcely available for Kogi State. Thus, a gap has emerged from the literature survey that is the basis of the research. This gap emanates from lack of significant literature on the subject in the area of study. It is envisaged that the current study will contribute significantly in terms of literature and policy recommendations on the subject matter.

\section{METHODOLOGY}

\section{Research Design}

The qualitative survey design was used for this study to elicit the opinions of respondents on the subject under investigation.

\section{Population, Sample and Sampling Techniques}

The population of the study was all primary school teachers of public schools in the twenty-one (21) Local Government Areas of Kogi State, Nigeria spread across the three Senatorial Districts of the state namely: Kogi East, Kogi West and Kogi Central. A sample of 1,500 teachers from a total of 6,850 teachers was drawn through stratified random sampling for the study. A disproportionate sub-sample of 500 from each of the three (3) Senatorial District was randomly selected to make up the 1,500 teachers that participated in the study.

\section{Research Instruments}

\section{Questionnaire}

The major instrument used for the study were questionnaires designed by the researcher to get opinions of respondents. The first one elicited response on possible indicators of dilapidation of schools while the second was on factors associated with achievement. They both contained nine (9) items and were designed on a scale of Strongly Disagree $=$ SD, Disagree = D, Agree =A, Strongly Agree $=$ SA with arithmetic values of 1, 2, 3 and 4 respectively.

\section{Interviews}

During the period of visiting, sharing and collecting the questionnaires from respondents in the schools, the researcher had the opportunity of interviewing some teachers on issues bothering on the study at hand. This was used to complement the major instrument. 
Journal of Education and Practice

ISSN 2520-467X (online)

Vol.4, Issue No.4, pp 14 - 42, 2020

www.carijournals.org

\section{Validity and Reliability of Instrument}

The questionnaires were given to one teacher and one head teacher per Senatorial District and two experts in measurement and evaluation to ascertain the validity of the items generated for the study. To test for the reliability of the questionnaire, the composite (value of all the individual items based on the three senatorial districts of the state) reliability score for each of the two aggregate dimensions of dilapidation and achievement in Kogi State, Nigeria were assessed using Cronbach's alpha. The coefficients were computed using data drawn from respondents from schools outside the schools sampled for this study. The coefficient for dilapidation of schools (DOS) was 0.753, and achievement of pupils based on teachers' perception (AOP) was 0.663. This justifies that all the items for the measures of dilapidation of schools and achievement based on teachers' perception in Kogi State, Nigeria were internally consistent.

\section{Data Collection}

The researcher was assisted by the Director of Local Governments, Education Secretaries, Head Teachers and Teachers in some cases to distribute and collect majority of the questionnaires to and from the respondents. The researcher went to the Director of Local Governments, Education Secretaries, Head Teachers offices to collect the filled questionnaires on later days. The researcher visited other schools, interacted with the teachers, administered and collected the questionnaire on same and later days as the case may be.

\section{Data Analysis}

The data generated from the respondents were organized in tabular forms after the four ratings used to design the questionnaires. They were analysed using Likert scale percentage analysis, correlation, mean score analysis, ranking, excel coding and SPSS. The data collected was also analyzed using Pearson correlation to determine relationships and test the stated hypothesis at 0 . 05 level of significance.

\section{DATA ANALYSIS AND DISCUSSION}

The following tables show the analysis of the data gathered from respondents concerning school dilapidation measures and pupils' achievement based on teachers' perceptions in Kogi State to answer the research questions and test the hypothesis stated for the study:

\section{Research Question One:}

What is the extent of dilapidation of schools by teachers' perspective exist in the three senatorial districts of Kogi State? 
Journal of Education and Practice

ISSN 2520-467X (online)

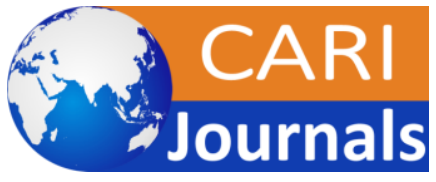

Vol.4, Issue No.4, pp 14 - 42, 2020

www.carijournals.org

Table 1: Percentage Item Analysis of School Dilapidation Measures in Central Senatorial District

\begin{tabular}{llllll}
\hline S/N & ITEMS & SA\% & A\% & D\% & SD\% \\
\hline 1 & Insufficient desk & 37.8 & 27.8 & 17.0 & 17.4 \\
2 & Large class size & 35.6 & 32.2 & 20.0 & 12.2 \\
3 & Licking class roof & 36.8 & 30.4 & 19.8 & 13.0 \\
4 & Not well lighted class & 31.6 & 33.8 & 18.2 & 16.4 \\
5 & Not well painted classroom & 30.4 & 26.0 & 28.6 & 15.0 \\
6 & Classes with cracked walls & 30.8 & 32.6 & 19.8 & 16.8 \\
7 & Classes with fallen walls & 34.6 & 29.4 & 21.6 & 14.4 \\
8 & Bad/damaged classroom seats & 38.2 & 34.6 & 13.6 & 13.6 \\
9 & Class roofs that are not well ceiled & 39.0 & 31.2 & 18.6 & 11.2 \\
\hline
\end{tabular}

Strongly Disagree $=S D$, Disagree $=D$, Agree $=A$, Strongly Agree $=S A$.

Table 1 depicted the information about the response on school dilapidation in central district. The item with statement "Class roofs that are not well ceiled" constitute the highest percentage score of $39.0 \%$, followed by the item with statement "Bad/damaged classroom seats" constituting $38.2 \%$. The Item with the third high percentage is a statement with "Insufficient desk" having $37.8 \%$. The Item with the fourth high percentage is a statement with "Licking class roof" having $36.8 \%$. The Item with the fifth high percentage is a statement with "Large class size" having $35.6 \%$. The Item with the sixth high percentage is a statement with "Classes with fallen walls" having $34.6 \%$. The Item with the seventh high percentage is a statement with "Not well lighted class" having 33.8\%. The Item with the eight high percentage is a statement with "Classes with cracked walls" having $32.6 \%$. The Item with the nineth high percentage is a statement with "Not well painted classroom" having $30.4 \%$.

Table 2: Percentage Item Analysis of School Dilapidation Measures in West Senatorial District

\begin{tabular}{llllll}
\hline S/N & ITEMS & SA\% & A\% & D\% & SD\% \\
\hline 1 & Insufficient desk & 47.8 & 38.8 & 9.0 & 4.4 \\
2 & Large class size & 24.0 & 39.4 & 30.2 & 6.4 \\
3 & Licking class roof & 36.4 & 50.8 & 8.2 & 4.6 \\
4 & Not well lighted class & 30.6 & 50.8 & 13.6 & 5.0 \\
5 & Not well painted classroom & 18.6 & 28.4 & 38.8 & 14.2 \\
6 & Classes with cracked walls & 31.0 & 46.8 & 14.6 & 7.6 \\
7 & Classes with fallen walls & 35.2 & 40.4 & 17.6 & 6.8 \\
8 & Bad/damaged classroom seats & 37.2 & 45.2 & 13.0 & 4.6 \\
9 & Class roofs that are not well ceiled & 30.4 & 45.4 & 17.4 & 6.8 \\
\hline
\end{tabular}

Strongly Disagree $=S D$, Disagree $=D$, Agree $=A$, Strongly Agree $=S A$.

Table 2 depicted the information about the response on school dilapidation in West district. The item with statement "Licking class roof and Not well lighted class" constitute the highest 
Journal of Education and Practice

ISSN 2520-467X (online)

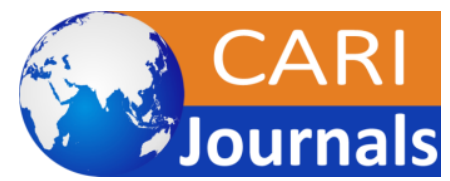

Vol.4, Issue No.4, pp 14 - 42, 2020

www.carijournals.org

percentage score of $50.8 \%$ respectively, followed by the item with statement "Class roofs that are not well ceiled" constituting $47.8 \%$. The Item with the third high percentage is a statement with "Classes with cracked walls" having $46.8 \%$. The Item with the fourth high percentage is a statement with "Bad/damaged classroom seats" having 45.4\%. The Item with the fifth high percentage is a statement with "Bad/damaged classroom seats" having $45.2 \%$. The Item with the sixth high percentage is a statement with "Classes with fallen walls" having $40.4 \%$. The Item with the seventh high percentage is a statement with "Large class size" having 39.4\%. The Item with the eight high percentage is a statement with "Not well painted classroom" having 38.8\%. Based on the respondents percentage analysis on school dilapidation all the items fall under the Likert scale (Strongly Agree and Agree) except item of Not well painted classroom that fall on under the Likert scale (Disagree).

Table 3: Percentage Item Analysis of School Dilapidation Measures in East Senatorial District

\begin{tabular}{llllll}
\hline S/N & ITEMS & SA\% & A\% & D\% & SD\% \\
\hline 1 & Insufficient desk & 42.4 & 31.8 & 14.4 & 11.4 \\
2 & Large class size & 41.0 & 29.0 & 21.0 & 9.0 \\
3 & Licking class roof & 45.6 & 29.4 & 14.0 & 11.0 \\
4 & Not well lighted class & 37.2 & 36.0 & 15.4 & 11.4 \\
5 & Not well painted classroom & 43.6 & 34.0 & 15.4 & 7.0 \\
6 & Classes with cracked walls & 38.8 & 36.6 & 14.6 & 10.0 \\
7 & Classes with fallen walls & 36.8 & 31.2 & 20.4 & 11.6 \\
8 & Bad/damaged classroom seats & 44.6 & 37.4 & 12.0 & 6.0 \\
9 & Class roofs that are not well ceiled & 44.4 & 33.4 & 12.8 & 9.4 \\
\hline
\end{tabular}

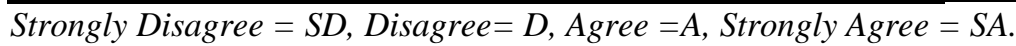

Table 3 depicted the information about the response on school dilapidation in East District. The item with statement "Licking class roof and Not well lighted class" constitute the highest percentage score of $45.6 \%$ respectively, followed by the item with statement "Bad/damaged classroom seats" constituting $44.6 \%$. The Item with the third high percentage is a statement with "Class roofs that are not well ceiled" having 44.4\%. The Item with the fourth high percentage is a statement with "Not well painted classroom" having 43.6\%. The Item with the fifth high percentage is a statement with "Insufficient desk" having 42.4\%. The Item with the sixth high percentage is a statement with "Large class size" having $41.0 \%$. The Item with the seventh high percentage is a statement with "Classes with cracked walls" having 38.8\%. The Item with the eight high percentage is a statement with "Classes with cracked walls" having $37.2 \%$. The Item with the ninth high percentage is a statement with "Classes with fallen walls" having $36.8 \%$. Based on the respondents percentage analysis on school dilapidation all the items fall under the Likert scale (Strongly Agree) except item of Not well painted classroom that fall on under the Likert scale (Disagree). 
Journal of Education and Practice

ISSN 2520-467X (online)

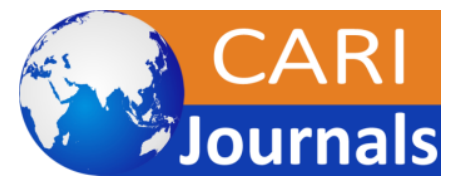

Vol.4, Issue No.4, pp 14 - 42, 2020

www.carijournals.org

Table 4: Item Analysis of School Dilapidation Using Mean Response Ranking by District in Kogi State

\begin{tabular}{llllllll}
\hline & & \multicolumn{2}{c}{ Central } & \multicolumn{3}{c}{ West } & \multicolumn{3}{c}{ East } \\
\hline S/ & ITEMS & Mean & Ranking & Mean & Ranking & Mean & Ranking \\
\hline 1 & Insufficient desk & 2.86 & 4 & 3.30 & 1 & 3.05 & 5 \\
2 & Large class size & 2.91 & 3 & 2.81 & 8 & 3.02 & 7 \\
3 & Licking class roof & 2.91 & 3 & 3.19 & 3 & 3.10 & 4 \\
4 & Not well lighted class & 2.81 & 6 & 3.07 & 4 & 2.99 & 8 \\
5 & Not well painted classroom & 2.72 & 8 & 2.51 & 9 & 3.14 & 2 \\
6 & Classes with cracked walls & 2.77 & 7 & 3.01 & 6 & 3.04 & 6 \\
7 & Classes with fallen walls & 2.84 & 5 & 3.04 & 5 & 2.93 & 9 \\
8 & Bad/damaged classroom seats & 2.97 & 2 & 3.15 & 2 & 3.21 & 1 \\
9 & Class roofs that are not well & & & & & & \\
& ceiled & 2.98 & 1 & 2.99 & 7 & 3.13 & 3 \\
\hline
\end{tabular}

On average response $=3.0$ (Agreement). Strongly Disagree $=1$, Disagree $=2$, Agree $=3$, Strongly Agree $=4$.

Table 4 suggest that the respondents agree to all the research items evaluating School Dilapidation across the three Senatorial Districts in Kogi State. The mean response ranking analysis indicates that most of the participants in the Central District said that class roofs that are not well ceiled ranking $1^{\text {st }}, \mathrm{Bad} /$ damaged classroom seats ranked $2^{\text {nd }}$, Large class size and Licking class roof ranked $3^{\text {rd }}$, Insufficient desk ranked $4^{\text {th }}$. In West district, mean response ranking analysis indicates that The results confirmed that Insufficient desk ranked $1^{\text {st }}$, Bad/damaged classroom seats ranked $2^{\text {nd }}$, Licking class roof ranked $3^{\text {rd }}$ and Not well lighted class ranked $4^{\text {th }}$. Also, in the East senatorial district, Bad/damaged classroom seats ranked $1^{\text {st }}$, Not well painted classroom ranked $2^{\text {nd }}$, Class roofs that are not okay $3^{\text {rd }}$ and Licking class roof ranked $4^{\text {th }}$.

Table 5: Percentage Item Analysis of School Dilapidation Using the Relative Importance Index (RII) by District in Kogi State

\begin{tabular}{llcccccc}
\hline & & Central & & West & \multicolumn{3}{c}{ East } \\
\hline S/N & ITEMS & RII & Ranking & RII & Ranking & RII & Ranking \\
\hline 1 & Insufficient desk & 0.72 & 4 & 0.83 & 1 & 0.76 & 5 \\
2 & Large class size & 0.73 & 3 & 0.70 & 7 & 0.76 & 5 \\
3 & Licking class roof & 0.73 & 3 & 0.80 & 2 & 0.77 & 4 \\
4 & Not well lighted class & 0.70 & 6 & 0.77 & 4 & 0.75 & 6 \\
5 & Not well painted classroom & 0.68 & 8 & 0.63 & 8 & 0.79 & 2 \\
6 & Classes with cracked walls & 0.69 & 7 & 0.75 & 6 & 0.76 & 5 \\
7 & Classes with fallen walls & 0.71 & 5 & 0.76 & 5 & 0.73 & 7 \\
8 & Bad/damaged classroom seats & 0.74 & 2 & 0.79 & 3 & 0.80 & 1 \\
9 & Class roofs that are not well ceiled & 0.75 & 1 & 0.75 & 6 & 0.78 & 3 \\
\hline
\end{tabular}

Table 5 shows the result of the Relative Importance Index (RII) results. The analysis reveals that in the Central District Insufficient desk, Large class size, Licking class roof, Not well painted classroom, Class roofs that are not well ceiled, Bad/damaged classroom seats and Classes with fallen walls contributed over $70 \%$ school dilapidation factors. In the West, relative importance 
Journal of Education and Practice

ISSN 2520-467X (online)

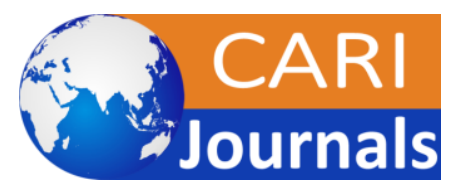

Vol.4, Issue No.4, pp 14 - 42, 2020

www.carijournals.org

index (RII) indicated that Insufficient desk, Licking class roof, Not well lighted class, Class roofs that are not well ceiled, Bad/damaged classroom seats, Classes with fallen walls, Classes with cracked walls and Not well lighted class accounted for $75 \%$ and above school dilapidation. In the East Senatorial district, the relative importance index (RII) suggested that Bad/damaged classroom seats, Class roofs that are not well ceiled, Classes with cracked walls, Not well painted classroom, Not well lighted class, Licking class roof, Insufficient desk and Large class size make up $75 \%$ to $80 \%$ factors of school dilapidation.

\section{Research Question Two:}

What is the level of pupils' achievement by teachers' perspective in the three Senatorial Districts of Kogi State?

Table 6: Percentage Item Analysis of Pupils' Achievement Measures in Central Senatorial District

\begin{tabular}{|c|c|c|c|c|c|}
\hline $\mathbf{S} / \mathbf{N}$ & ITEMS & SA\% & $\mathbf{A} \%$ & D\% & SD\% \\
\hline 1. & Has the school structure positively affect learning & 10.0 & 16.0 & 42.0 & 32.0 \\
\hline 2. & High learning interest demonstrated by pupils & 12.8 & 16.6 & 55.0 & 15.6 \\
\hline 3. & Attitude of pupils are key to learning & 35.8 & 29.2 & 17.2 & 17.8 \\
\hline 4. & Pupils' spent high quality time in school for effective learning & 14.0 & 13.4 & 45.6 & 27.0 \\
\hline 5. & Time management, skills and competencies are achieved & 26.0 & 26.0 & 35.0 & 13.0 \\
\hline 6. & Learning objectives are generally achieved & 8.4 & 19.6 & 55.0 & 17.0 \\
\hline \multirow{2}{*}{$\begin{array}{l}7 . \\
8 .\end{array}$} & Pupils' tests scores and grade are encouraging to learning achievements & 21.2 & 28.8 & 32.8 & 17.2 \\
\hline & On ground school plants contributes to pupils' learning achievement & 9.4 & 17.4 & 46.4 & 26.8 \\
\hline 9. & On whole, academic/achievement performance of pupils are rated high & 8.6 & 16.8 & 53.6 & 21.0 \\
\hline
\end{tabular}

Strongly Disagree $=S D$, Disagree $=D$, Agree $=A$, Strongly Agree $=S A$.

Table 6 depicted the information about the response on pupils' achievement in Central District. The item with statement "Learning objectives are generally achieved and High learning interest demonstrated by pupils" constitute the highest percentage score of $55.0 \%$ respectively, followed by the item with statement "On whole, academic/achievement performance of pupils are rated high" constituting 53.6\%. The Item with the third high percentage is a statement with "On ground school plants contributes to pupils' learning achievement" having $46.4 \%$. The Item with the fourth high percentage is a statement with "Pupils' spent high quality time in school for effective learning" having 45.6\%. The Item with the fifth high percentage is a statement with "Has the school structure positively affect learning" having $42.0 \%$. The Item with the sixth high percentage is a statement with "Attitude of pupils are key to learning" having 35.8\%. The Item with the seventh high percentage is a statement with "Time management, skills and competencies are achieved" having 35.0\%. The Item with the eight high percentage is a statement with "Pupils' tests scores and grade are encouraging to learning achievements" having 32.8\%. \%. Based on the respondents percentage analysis of teachers' perception on pupils' achievement all the items fall under the Likert scale (Disagree) except item of Attitude of pupils are key to learning that fall on under the Likert scale (Strongly Agree). 
Journal of Education and Practice

ISSN 2520-467X (online)

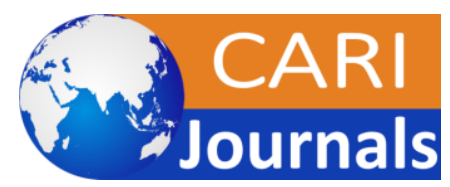

Vol.4, Issue No.4, pp 14 - 42, 2020

www.carijournals.org

Table 7: Percentage Item Analysis of Pupils' Achievement Measures in West Senatorial District

\begin{tabular}{lllll}
\hline ITEMS & SA \% & A\% & D\% & SD\% \\
\hline Has the school structure positively affect learning & 26.0 & 25.4 & 29.6 & 19.0 \\
High learning interest demonstrated by pupils & 24.8 & 24.4 & 27.6 & 23.2 \\
Attitude of pupils are key to learning & 30.4 & 29.4 & 22.0 & 18.2 \\
Pupils' spent high quality time in school for effective learning & 14.0 & 27.6 & 36.2 & 22.2 \\
Time management, skills and competencies are achieved & 14.0 & 26.6 & 32.8 & 26.6 \\
Learning objectives are generally achieved & 14.4 & 21.2 & 32.8 & 31.6 \\
Pupils' tests scores and grade are encouraging to learning achievements & 19.0 & 24.8 & 28.4 & 27.8 \\
On ground school plants contributes to pupils' learning achievement & 15.6 & 23.6 & 31.6 & 29.2 \\
On whole, academic/achievement performance of pupils are rated high & 10.0 & 17.6 & 41.0 & 31.4 \\
\hline
\end{tabular}

Strongly Disagree $=S D$, Disagree $=D$, Agree $=A$, Strongly Agree $=S A$.

Table 7 depicted the information about the response on pupils' achievement in West District. The item with statement "On whole, academic/achievement performance of pupils are rated high" constitute the highest percentage score of $41.0 \%$, followed by the item with statement "Pupils' spent high quality time in school for effective learning" constituting $36.2 \%$. The Item with the third high percentage is a statement with "Time management, skills and competencies are achieved and Learning objectives are generally achieved" having $32.8 \%$ respectively. The Item with the fourth high percentage is a statement with "On ground school plants contributes to pupils' learning achievement" having 31.6\%. The Item with the fifth high percentage is a statement with "Attitude of pupils are key to learning" having 30.4\%. The Item with the sixth high percentage is a statement with "Has the school structure positively affect learning" having $29.6 \%$. The Item with the seventh high percentage is a statement with "Pupils' tests scores and grade are encouraging to learning achievements" having $28.4 \%$. The Item with the eight high percentage is a statement with "High learning interest demonstrated by pupils" having 27.6\%. \%. Based on the respondents percentage analysis of teachers' perception on pupils' achievement all the items fall under the Likert scale (Disagree) except item of Attitude of pupils are key to learning that fall on under the Likert scale (Strongly Agree).

Table 8: Percentage Item Analysis of Pupils' Achievement Measures in East Senatorial District

\begin{tabular}{lllll}
\hline ITEMS & SA\% & A\% & D\% & SD\% \\
\hline Has the school structure positively affect learning & 28.0 & 31.0 & 22.0 & 19.0 \\
High learning interest demonstrated by pupils & 23.8 & 20.8 & 34.4 & 21.0 \\
Attitude of pupils are key to learning & 27.6 & 31.8 & 28.4 & 12.2 \\
Pupils' spent high quality time in school for effective learning & 12.0 & 22.4 & 34.8 & 30.8 \\
Time management, skills and competencies are achieved & 13.4 & 23.6 & 34.4 & 28.6 \\
Learning objectives are generally achieved & 19.0 & 19.8 & 32.8 & 28.4 \\
Pupils' tests scores and grade are encouraging to learning achievements & 19.2 & 22.8 & 33.4 & 24.6 \\
On ground school plants contributes to pupils' learning achievement & 21.6 & 30.4 & 27.6 & 20.4 \\
On whole, academic/achievement performance of pupils are rated high & 13.6 & 17.8 & 41.2 & 27.4 \\
\hline
\end{tabular}


Journal of Education and Practice

ISSN 2520-467X (online)

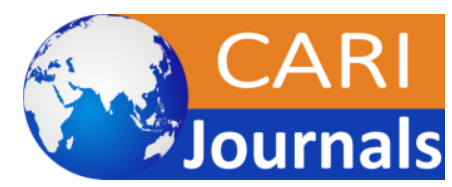

Vol.4, Issue No.4, pp 14 - 42, 2020

www.carijournals.org

Table 8 depicted the information about the response on pupils' achievement in East District. The item with statement "On whole, academic/achievement performance of pupils are rated high" constitute the highest percentage score of $41.2 \%$, followed by the item with statement "Pupils' spent high quality time in school for effective learning" constituting $34.8 \%$. The Item with the third high percentage is a statement with "High learning interest demonstrated by pupils and Time management, skills and competencies are achieved" having $34.4 \%$ respectively. The Item with the fourth high percentage is a statement with "Pupils' tests scores and grade are encouraging to learning achievements" having 33.4\%. The Item with the fifth high percentage is a statement with "Learning objectives are generally achieved" having 32.8\%. The Item with the sixth high percentage is a statement with "Attitude of pupils are key to learning" having $31.8 \%$. The Item with the seventh high percentage is a statement with "Has the school structure positively affect learning" having $31.0 \%$. The Item with the eight high percentage is a statement with "On ground school plants contributes to pupils' learning achievement" having $30.4 \%$. Based on the respondents percentage analysis of teachers' perception on pupils' achievement all the items fall under the Likert scale (Disagree) except item of Attitude of pupils are key to learning; Has the school structure positively affect learning and On ground school plants contributes to pupils' learning achievement that fall on under the Likert scale (Strongly Agree and Agree).

Table 9: Item Analysis of School Achievement Using Mean Response Ranking by District in Kogi State

\begin{tabular}{|c|c|c|c|c|c|c|}
\hline & Central & & West & & East & \\
\hline ITEMS & Mean & Ranking & Mean & Ranking & Mean & Ranking \\
\hline $\begin{array}{l}\text { Has the school structure positively affect } \\
\text { learning }\end{array}$ & 2.04 & 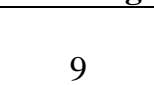 & 2.58 & 0 & 2.68 & $8=0$ \\
\hline High learning interest demonstrated by pupils & 2.27 & 4 & 2.51 & 3 & 2.47 & 4 \\
\hline Attitude of pupils are key to learning & 2.83 & 1 & 2.72 & 1 & 2.75 & 1 \\
\hline $\begin{array}{l}\text { Pupils' spent high quality time in school for } \\
\text { effective learning }\end{array}$ & 2.14 & 6 & 2.33 & 5 & 2.16 & 9 \\
\hline $\begin{array}{l}\text { Time management, skills and competencies } \\
\text { are achieved }\end{array}$ & 2.65 & 2 & 2.28 & 6 & 2.22 & 8 \\
\hline Learning objectives are generally achieved & 2.19 & 5 & 2.18 & 8 & 2.29 & 6 \\
\hline $\begin{array}{l}\text { Pupils' tests scores and grade are encouraging } \\
\text { to learning achievements }\end{array}$ & 2.54 & 3 & 2.35 & 4 & 2.37 & 5 \\
\hline $\begin{array}{l}\text { On ground school plants contributes to } \\
\text { pupils' learning achievement }\end{array}$ & 2.09 & 8 & 2.26 & 7 & 2.53 & 3 \\
\hline $\begin{array}{l}\text { On whole, academic/achievement } \\
\text { performance of pupils are rated high }\end{array}$ & 2.13 & 7 & 2.06 & 9 & 2.18 & 7 \\
\hline
\end{tabular}

On average response $=3.0$ (Agreement). Strongly Disagree $=1$, Disagree $=2$, Agree $=3$, Strongly Agree $=4$.

Table 9 reveals that the respondents agree to all the research items attitude of pupils are key to learning, time management, skills and competencies are achieved and pupils' tests scores and grade are encouraging to learning. There is overwhelming opinion that academic/achievement performance of pupils are not rated high. In addition, on ground school plants do not contribute to pupils' learning achievement; learning objectives are not generally achieved; pupils do not spent high quality time in school for effective learning. There is no high learning interest demonstrated by pupils and the school structure has not positively affect learning in Central District evaluation 
Journal of Education and Practice

ISSN 2520-467X (online)

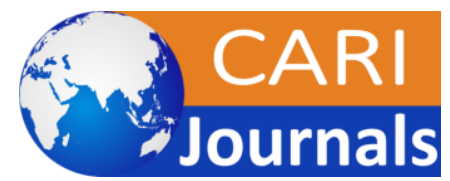

Vol.4, Issue No.4, pp 14 - 42, 2020

www.carijournals.org

of pupils' achievement. The mean response ranking analysis indicates that most of the participants in the Central District said that Attitude of pupils are key to learning ranking $1^{\text {st }}$, Time management, skills and competencies are achieved ranked $2^{\text {nd }}$, Pupils' tests scores and grade are encouraging to learning achievements ranked $3^{\text {rd }}$ and High learning interest demonstrated by pupils ranked $4^{\text {th }}$. In the West district, there was agreement to Has the school structure positively affect learning, High learning interest demonstrated by pupils and Attitude of pupils are key to learning to pupils' achievement. However, there was disagreement to items measures. Attitude of pupils are key to learning ranked $1^{\text {st }}$, Has the school structure positively affect learning ranked $2^{\text {nd }}$, High learning interest demonstrated by pupils ranked $3^{\text {rd }}$ and Pupils' tests scores and grade are encouraging to learning achievements ranked $4^{\text {th }}$. In the East senatorial district, respondents agreed that Has the school structure positively affect learning, Attitude of pupils are key to learning and On ground school plants contributes to pupils' learning achievement to pupils' achievement. The result of the mean ranking analysis reveals that Attitude of pupils are key to learning ranked $1^{\text {st }}$, Has the school structure positively affect learning ranked $2^{\text {nd }}$, On ground school plants contributes to pupils' learning achievement ranked $3^{\text {rd }}$ and High learning interest demonstrated by pupils ranked $4^{\text {th }}$.

Table 10: Percentage Item Analysis of School Achievement Using Relative Importance Index (RII) by District in Kogi State.

\begin{tabular}{|c|c|c|c|c|c|c|c|}
\hline & & Central & & West & & East & \\
\hline $\mathbf{S} / \mathbf{N}$ & ITEMS & RII & Ranking & RII & Ranking & RII & Ranking \\
\hline 1. & $\begin{array}{l}\text { Has the school structure positively } \\
\text { affect learning }\end{array}$ & 0.51 & 9 & 0.65 & 2 & 0.67 & 2 \\
\hline 2. & $\begin{array}{l}\text { High learning interest demonstrated by } \\
\text { pupils }\end{array}$ & 0.57 & 4 & 0.63 & 3 & 0.62 & 4 \\
\hline 3. & Attitude of pupils are key to learning & 0.71 & 1 & 0.68 & 1 & 0.69 & 1 \\
\hline 4. & $\begin{array}{l}\text { Pupils' spent high quality time in } \\
\text { school for effective learning }\end{array}$ & 0.54 & 6 & 0.58 & 5 & 0.54 & 8 \\
\hline 5. & $\begin{array}{l}\text { Time management, skills and } \\
\text { competencies are achieved }\end{array}$ & 0.66 & 2 & 0.57 & 6 & 0.55 & 7 \\
\hline 6. & $\begin{array}{l}\text { Learning objectives are generally } \\
\text { achieved }\end{array}$ & 0.55 & 5 & 0.55 & 8 & 0.57 & 6 \\
\hline 7. & $\begin{array}{l}\text { Pupils' tests scores and grade are } \\
\text { encouraging to learning achievements }\end{array}$ & 0.64 & 3 & 0.59 & 4 & 0.59 & 5 \\
\hline 8. & $\begin{array}{l}\text { On ground school plants contributes to } \\
\text { pupils' learning achievement }\end{array}$ & 0.52 & 8 & 0.56 & 7 & 0.63 & 3 \\
\hline 9. & $\begin{array}{l}\text { On whole, academic/achievement } \\
\text { performance of pupils are rated high }\end{array}$ & 0.53 & 7 & 0.52 & 9 & 0.54 & 8 \\
\hline
\end{tabular}

On average response $=3.0$ (Agreement). Strongly Disagree $=1$, Disagree $=2$, Agree $=3$, Strongly Agree $=4$.

Table 10 shows the result the Relative Importance Index (RII) of pupils' achievements result. The analysis reveals that in the Central District Attitude of pupils are key to learning, Time management, skills and competencies are achieved, Pupils' tests scores and grade are encouraging to learning achievements contributed over $60 \%$ pupils' achievement factors. In the West, relative importance index (RII) indicated that Attitude of pupils are key to learning, High learning interest demonstrated by pupils, Has the school structure positively affect learning accounted for $60 \%$ and 
Journal of Education and Practice

ISSN 2520-467X (online)

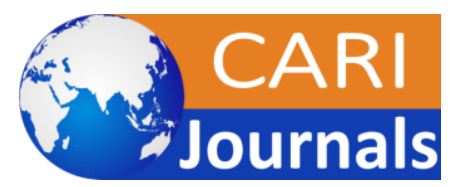

Vol.4, Issue No.4, pp 14 - 42, 2020

www.carijournals.org

above pupils' achievement. In the East senatorial district, the relative importance index (RII) suggested that Attitude of pupils are key to learning, High learning interest demonstrated by pupils, Has the school structure positively affect learning and On ground school plants contributes to pupils' learning achievement make up $60 \%$ to $65 \%$ factors of pupils' achievement.

\section{Research Question Three:}

What relationship exists in the state of dilapidation of schools by teachers' perspective in the three senatorial districts of Kogi State?

Table 11: Result of Correlation Analysis of School Dilapidation in Kogi State

\begin{tabular}{lccc}
\hline District & $\mathbf{R}$ & $\mathbf{p}<\mathbf{0 . 0 5}$ & Remark \\
\hline Central* West & 0.418 & 0.262 & Not Sig. \\
Central* East & 0.205 & 0.597 & Not Sig. \\
East* West & $0.821 * *$ & 0.007 & Sig. \\
\hline
\end{tabular}

The correlation analysis of school dilapidation across the senatorial districts suggest that there is weak between Central and West alongside the East District. This is not statistically significant.

\section{Research Question Four:}

What relationship exists in the state of pupils' achievement in schools by teachers' perspective in the three senatorial districts of Kogi State?

Table 12: Result of Correlation Analysis of Pupils' Achievement in Kogi State

\begin{tabular}{lccc}
\hline District & $\mathbf{R}$ & $\mathbf{p}<\mathbf{0 . 0 5}$ & Remark \\
\hline Central* West & 0.423 & 0.257 & Not Sig. \\
Central* East & 0.204 & 0.598 & Not Sig. \\
East* West & $0.835^{* *}$ & 0.005 & Sig. \\
\hline
\end{tabular}

The correlation analysis of pupils' achievement based on teachers' perception across the senatorial districts indicates that there is weak among the Central, West and the East senatorial district. This is not statistically significant.

\section{Research Question Five:}

What Comparison exists in the factor measures of dilapidation within Kogi State?

Table 13: Tests of Between-Subjects Effects

\begin{tabular}{|c|c|c|c|c|c|}
\hline \multicolumn{6}{|c|}{ Dependent Variable: Dilapidation } \\
\hline Source & Sum of Squares & Df & \multicolumn{2}{|c|}{ Mean Square F } & Sig. \\
\hline School Dilapidation Measures & .240 & 8 & .030 & 1.537 & .221 \\
\hline District & .199 & 2 & .099 & 5.098 & .019 \\
\hline Error & .312 & 16 & .019 & & \\
\hline Total & .750 & 26 & & & \\
\hline Pupils' Achievement Measures & .842 & 8 & .105 & 3.308 & .020 \\
\hline District & .033 & 2 & .016 & .518 & .605 \\
\hline Error & .509 & 16 & .032 & & \\
\hline Total & 1.384 & 26 & & & \\
\hline
\end{tabular}

a. $R$ Squared $=.584$ (Adjusted $R$ Squared $=.325)$ 
Journal of Education and Practice

ISSN 2520-467X (online)

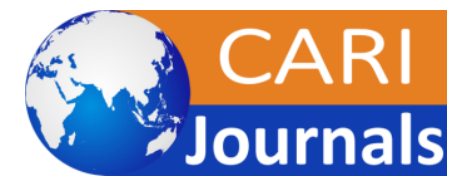

Vol.4, Issue No.4, pp 14 - 42, 2020

www.carijournals.org

Table 14: Post Hoc Tests

\section{Multiple Comparisons}

Dependent Variable: Dilapidation

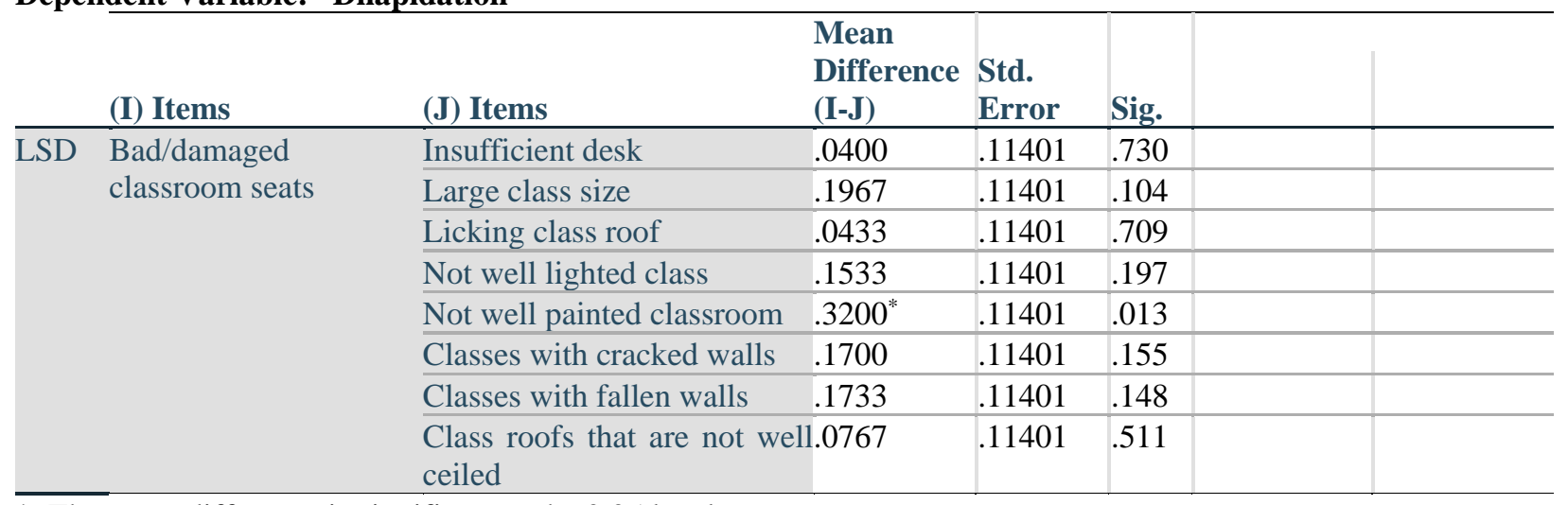

*. The mean difference is significant at the 0.05 level.

In comparing the factor measures of dilapidation across the Senatorial Districts in Kogi State, the Least Significant Difference (LSD) test suggests that there is significant difference in schools dilapidation. Bad/damaged classroom seats tends to be statistically significant to Not well painted classroom as the associated mean probability values are less than 0.05 at $5 \%$. Bad/damaged classroom seats as compared to other school dilapidation measures of perception of teachers across the districts in the Kogi State are not significant as the associated mean probability values are less than 0.05 at $5 \%$.

Table 15: Homogeneous Subsets

\begin{tabular}{|c|c|c|c|c|}
\hline \multicolumn{5}{|c|}{ Dilapidation } \\
\hline & \multirow[b]{2}{*}{ Items } & \multicolumn{3}{|c|}{ Subset } \\
\hline & & $\mathbf{N}$ & 1 & 2 \\
\hline \multirow[t]{10}{*}{$\overline{\text { Duncan }^{\mathrm{a}, \mathrm{b}}}$} & Not well painted classroom & 3 & 2.7900 & \\
\hline & Large class size & 3 & 2.9133 & 2.9133 \\
\hline & Classes with fallen walls & 3 & 2.9367 & 2.9367 \\
\hline & Classes with cracked walls & 3 & 2.9400 & 2.9400 \\
\hline & Not well lighted class & 3 & 2.9567 & 2.9567 \\
\hline & Class roofs that are not well ceiled & 3 & 3.0333 & 3.0333 \\
\hline & Licking class roof & 3 & & 3.0667 \\
\hline & Insufficient desk & 3 & & 3.0700 \\
\hline & Bad/damaged classroom seats & 3 & & 3.1100 \\
\hline & Sig. & & .074 & .148 \\
\hline
\end{tabular}

Based on the results of Duncan Multiple Range Test, the school dilapidation measures such as $\mathrm{Bad}$ /damaged classroom seats, Insufficient desk, Licking class roof and Class roofs that are not well ceiled constituted higher percentage factors of degree of school dilapidation in Kogi State. 
Journal of Education and Practice

ISSN 2520-467X (online)

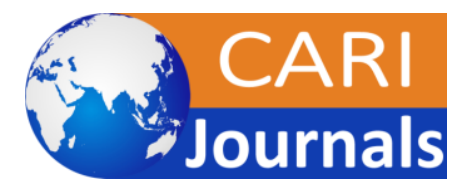

Vol.4, Issue No.4, pp 14 - 42, 2020

$\underline{\text { Www.carijournals.org }}$

Table 16: District

\begin{tabular}{|c|c|c|c|c|c|}
\hline \multicolumn{6}{|c|}{ Multiple Comparisons } \\
\hline \multicolumn{6}{|c|}{ Dependent Variable: Dilapidation } \\
\hline & (I) District & (J) District & Mean Difference (I-J) & Std. Error & Sig. \\
\hline \multirow[t]{2}{*}{ LSD } & East Senatorial District & Central Senatorial District & $.2044 *$ & 0.06582 & 0.007 \\
\hline & & West Senatorial District & 0.06 & 0.06582 & 0.376 \\
\hline
\end{tabular}

In comparing the factor measures of school dilapidation in Kogi State, the Least Significant Difference (LSD) test suggests that there is significant difference in the level of school dilapidation in the East Senatorial District and Central Senatorial District. However, East Senatorial District and West Senatorial District are not significant. This implies that East Senatorial District and West Senatorial District suffer the same faith of school dilapidation in the Kogi State since the associated mean probability values are greater than 0.05 at $5 \%$.

Table 17: Homogeneous Subsets

Dilapidation

\begin{tabular}{|c|c|c|c|c|}
\hline & & & Subset & \\
\hline & District & $\mathbf{N}$ & 1 & 2 \\
\hline$\overline{\text { Duncan }^{\mathrm{a}, \mathrm{b}}}$ & Central Senatorial District & 9 & 2.8633 & \\
\hline & West Senatorial District & 9 & & 3.0078 \\
\hline & East Senatorial District & 9 & & 3.0678 \\
\hline & Sig. & & 1.000 & .376 \\
\hline
\end{tabular}

Based on the results of Duncan Multiple Range Test, the school dilapidation is much more evidence in East and West senatorial district in Kogi State.

\section{Research Question Six:}

What Comparison exists in the factor measures of achievement within Kogi State?

\section{Table 18: Post Hoc Tests}

Items

Multiple Comparisons

Dependent Variable: Achievement

\section{Multiple Comparisons}

Dependent Variable: Dilapidation

\begin{tabular}{lllccc}
\hline \multirow{2}{*}{ LSD } & (I) District & (J) District & Mean Difference (I-J) & Std. Error & Sig. \\
& East Senatorial District & Central Senatorial District & $.2044 *$ & 0.06582 & 0.007 \\
& & West Senatorial District & 0.06 & 0.06582 & 0.376 \\
\hline
\end{tabular}

In comparing the factor measures of achievement across the senatorial districts in Kogi State, the Least Significant Difference (LSD) test suggests that there is significant difference in the pupils' achievement. Attitude of pupils as key to learning tends to be statistically significant as compared to other achievement measures of pupils' achievement perception of teachers across the districts in the Kogi State since the associated mean probability values are less than 0.05 at $5 \%$. 
Journal of Education and Practice

ISSN 2520-467X (online)

Vol.4, Issue No.4, pp 14 - 42, 2020

www.carijournals.org

Table 19: Homogeneous Subsets

\begin{tabular}{llll}
\hline Achievement & & \\
\hline Items & N & Subset \\
\hline Duncana,b & \multicolumn{1}{c}{$\mathbf{2}$} \\
& On whole, academic/achievement performance of pupils are rated high & 3 & 2.1233 \\
& Pupils' spent high quality time in school for effective learning & 3 & 2.21 \\
Learning objectives are generally achieved & 3 & 2.22 \\
On ground school plants contributes to pupils' learning achievement & 3 & 2.2933 \\
Time management, skills and competencies are achieved & 3 & 2.3833 \\
High learning interest demonstrated by pupils & 3 & 2.4167 \\
Pupils' tests scores and grade are encouraging to learning achievements & 3 & 2.42 \\
Has the school structure positively affect learning & 3 & 2.4333 \\
Attitude of pupils are key to learning & 3 & \multicolumn{2}{c}{2.7667} \\
Sig. & \multicolumn{2}{c}{0.079} \\
\hline
\end{tabular}

In terms of pupils' achievement, the results of Duncan Multiple Range Test suggests that among the measures of achievement of pupils in Kogi school system, Attitude of pupils are key to learning is the most outstanding across the senatorial districts. However, lower performance factors were recorded in terms of academic/achievement performance of pupils. Also rated high are Pupils' spent high quality time in school for effective learning. Learning objectives are generally achieved. Time management, skills and competencies are achieved.

Table 20: District

Multiple Comparisons

Dependent Variable: Achievement

\begin{tabular}{lllccc}
\hline & (I) District & (J) District & Mean Difference (I-J) & Std. Error & Sig. \\
\hline \multirow{2}{*}{ LSD } & East Senatorial District & Central Senatorial District & 0.0856 & 0.08407 & 0.324 \\
& & West Senatorial District & 0.0422 & 0.08407 & 0.622 \\
\hline
\end{tabular}

In testing the significance of the factor measures of pupils' achievement based on teachers perception in Kogi State, the Least Significant Difference (LSD) test suggests that there is no significant difference in the pupils' achievement in all the senatorial districts. Measures of pupils' achievement perception of teachers across the districts in the Kogi State are the same since the associated mean probability values are greater than 0.05 at $5 \%$. 
Journal of Education and Practice

ISSN 2520-467X (online)

Vol.4, Issue No.4, pp 14 - 42, 2020

www.carijournals.org

Table 21: Homogeneous Subsets

\begin{tabular}{llll}
\hline Achievement & & & \\
\hline & District & N & Subset \\
\hline Duncana,b & & \multicolumn{1}{c}{$\mathbf{1}$} \\
& Central Senatorial District & 9 & 2.32 \\
& West Senatorial District & 9 & 2.3633 \\
& East Senatorial District & 9 & 2.4056 \\
& Sig. & & 0.349 \\
\hline
\end{tabular}

In terms of pupils' achievement, the results of Duncan Multiple Range Test suggests that among the measures of achievement of pupils in Kogi school system, it was highly discouraging given the mean response value within 2.0 (disagreement).

\section{Research Question Seven:}

What is the relationship between dilapidation of schools and pupils' achievement in Kogi State as perceived by teachers?

Table 22: Correlation of School Dilapidation and Achievement

\begin{tabular}{llll}
\hline Variables & R & P & Level \\
\hline $\begin{array}{l}\text { School Achievement } \\
\text { School Dilapidation } \\
\text { (RMS) }\end{array}$ & - & - & - \\
\hline
\end{tabular}

** Correlation is significant at 0.05 level (2 tailed)

The data collected was analyzed using Pearson correlation to determine the relationship. Table 22 depicted the correlation analysis between school dilapidation and school achievement in Kogi state. The value of the correlation coefficient was, $r=0.134$. Thus, a positive relationship exists between school dilapidation and school achievement.

Table 23 Model Summary

\begin{tabular}{|c|c|c|c|c|c|c|c|c|c|c|}
\hline \multirow{2}{*}{\multicolumn{2}{|c|}{ Model R }} & \multirow{2}{*}{\multicolumn{2}{|c|}{$\begin{array}{r}\text { Adjusted } \\
\text { R SquareSquare } \\
\end{array}$}} & \multicolumn{5}{|c|}{ Change Statistics } & \multirow{3}{*}{$\begin{array}{l}\begin{array}{l}\text { Sig. } \\
\text { Change }\end{array} \\
731\end{array}$} & \multirow{3}{*}{$\mathbf{F}$} \\
\hline & & & & $\begin{array}{r}\text { RStd. Er } \\
\text { the Est }\end{array}$ & $\begin{array}{l}\text { R Sq } \\
\text { Change }\end{array}$ & F Ch & df1 & df 2 & & \\
\hline 1 & $.134^{\mathrm{a}}$ & .018 & -.122 & .20001 & .018 & .128 & 1 & 7 & & \\
\hline
\end{tabular}

a. Predictors: (Constant), School Dilapidation

From Table 23, it was shown that the R-square for the model was 0.018 implies that the school dilapidation on school achievement in Kogi State, Nigeria showed about $1.8 \%$ of the variance in management style (MS). Thus, the remaining98.2\% is due to other factors and residuals. Also, the multiple $\mathrm{R}(\mathrm{R}=\mathrm{.134})$ revealed a significant low positive relationship between independent variable (school dilapidation) and dependent variable (school achievement). 
Journal of Education and Practice

ISSN 2520-467X (online)

Vol.4, Issue No.4, pp 14 - 42, 2020

www.carijournals.org

Table 24: ANOVA ${ }^{b}$

\begin{tabular}{lllllll}
\hline Model & & Sum of Squares & df & Mean Square & F & Sig. \\
\hline 1 & Regression & .005 & 1 & .005 & .128 & $.731^{\mathrm{b}}$ \\
\cline { 2 - 5 } & Residual & .280 & 7 & .040 & & \\
& Total & .285 & 8 & & & \\
\hline
\end{tabular}

a. Dependent Variable: School Achievement

b. Predictors: (Constant), School Dilapidation

Table 24 indicates that the result of the analysis shows that $F$ value was significant $(F=0.128$, $\mathrm{p}=.731$ ). This shows that the model was valid but very weak.

Table 25 Coefficients ${ }^{\mathrm{a}}$

\begin{tabular}{|c|c|c|c|c|c|c|}
\hline \multirow{2}{*}{\multicolumn{2}{|c|}{ Model }} & \multicolumn{2}{|c|}{ Unstandardized Coefficients } & \multirow{2}{*}{$\begin{array}{c}\text { Standardized } \\
\text { Coefficients } \\
\text { Beta } \\
\end{array}$} & \multirow[b]{2}{*}{$\mathbf{t}$} & \multirow[b]{2}{*}{ Sig. } \\
\hline & & $\beta$ & Std. Error & & & \\
\hline \multirow[t]{2}{*}{1} & (Constant) & 1.608 & 2.106 & & .764 & .470 \\
\hline & School Dilapidation & -.253 & .706 & .134 & .358 & .731 \\
\hline
\end{tabular}

a. Dependent Variable: School Achievement

Based on the regression analysis, the model consists of one predicting variable(school dilapidation). Thus, the prediction equation of the school achievement in Kogi State, Nigeria and the proposed model is as follows:

$$
\hat{Y}=\beta_{0+} \beta_{1} X+e_{i} \ldots
$$

Where:

$\hat{\mathrm{Y}}=$ (the dependent variable) School achievement

$\mathrm{a}=$ the intercept / regression constant

$\beta=$ the slope, or regression coefficient of each variables.

$X=$ School Dilapidation,

ei=Error terms assumed to have zero mean and constant variables

The estimated model of the study is expressed as:

School Achievement=1.608+ 0.253School Dilapidation

In comparing the contribution of each independent variable, Beta values are used. As illustrated in the coefficient Betas column, influence of school dilapidation on school achievement makes the moderate unique contribution to explaining school achievement with $(\beta=0.253)$.

\section{Test of Hypothesis}

There is no significant relationship between dilapidated school structures and the academic achievement of primary school pupils in Kogi state. 
Journal of Education and Practice

ISSN 2520-467X (online)

Vol.4, Issue No.4, pp 14 - 42, 2020

www.carijournals.org

Table 26: Correlation of School Dilapidation and Achievement

\begin{tabular}{llll}
\hline Variables & R & P & Level \\
\hline $\begin{array}{l}\text { School Achievement } \\
\text { School Dilapidation }\end{array}$ & - & - & - \\
(RMS) & 0.134 & 0.731 & Low \\
\hline$* *$ Correlation is significant at 0.05 level (2 tailed) & & &
\end{tabular}

Table 26 depicted the correlation analysis between school dilapidation and school achievement in Kogi State. The results were found to be; school dilapidation and school achievement, $\mathrm{p}=0.731$. From the $\mathrm{p}$ value, the null hypothesis is not rejected. We therefore accept the hypothesis that there is no significant relationship between school dilapidation and school achievement.

\section{Discussion of Results}

On the extent of dilapidation of schools in the three Senatorial Districts of Kogi State, the findings show that there is a general opinion in the central of Kogi State on all item measures that school dilapidation exists with Class roofs that are not well ceiled, Bad/damaged classroom seats and Insufficient desk constituting greater percentages of the state of school dilapidation in the district. For the West District of Kogi State, the item measures showed that school dilapidation exists, except for Not well painted. Classroom with Licking class roof, Not well lighted class, Class roofs that are not well ceiled and Classes with cracked walls contributed greater percentages of the state of school dilapidation in the district. Also, there was a general opinion in the East District of Kogi State that, school dilapidation exists with Bad/damaged classroom seats, Class roofs that are not well ceiled, Not well painted classroom and Insufficient deskcontributing greater percentages of the state of school dilapidation in the District. Clearly, across the Senatorial Districts, there are varying degrees of level of school dilapidation in Kogi State. The results confirmed that school dilapidation across the three Senatorial Districts in Kogi State exists and were generally characterized by Bad/damaged classroom seats, Licking class roof and Insufficient desk in Kogi State.Nwagwu as cited by Adamu(2015) maintained that the quality of education that children receive bears direct relevance to the availability or lack of physicalfacilities and overall atmosphere in which learning takes place. Similarly, In a related development, Mudassir and Norsuhaily, (2015) conducted a study to examine how school environment influence students' academic performance in selected secondary schools within Kuala Terengganu. The result of the study indicated that students from a school with adequate facilities, good teachers and favorable environment perform better than those from schools with fewer facilities, unqualified teachers and less enabling environment. Thus, poorer achievement was associated with specific building condition factors such as standard science facilities, air conditioning, locker conditions, classroom furniture, more graffiti, and noisy external environments. With the findings of these earlier researches, the government of Kogi State will do well by taking a look at where learning occurs in the state if it must experience improved performances among pupils in primary school.

On the level of pupils' achievement in the three senatorial districts of Kogi State, the teachers' opinion in the Central district show that, learning objectives are not generally achieved; high learning interest is not demonstrated by pupils, on whole, academic/achievement performance of pupils are not rated high Also, On ground school plants does not contribute to pupils' learning achievement. In addition, pupils do not spent high quality time in school for effective learning. 
Journal of Education and Practice

ISSN 2520-467X (online)

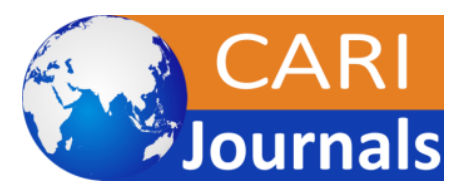

Vol.4, Issue No.4, pp 14 - 42, 2020

www.carijournals.org

Interestingly, there was a very strong agreement that Attitude of pupils is key to learning based on teachers' perception. Again, in the West senatorial district, the findings show that, on whole, academic/achievement performance of pupils are not rated high; pupils do not spent high quality time in school for effective learning; time management, skills and competencies and learning objectives are not generally achieved. On ground school plants does not contribute to pupils' learning achievement. Interestingly, there was a very strong agreement that Attitude of pupils is key to learning. The question that readily comes to mind here is, could it be that the pupils are demotivated because of the state of dilapidation of the school structures? In this regard, a study reported by Mgbodile as cited by Osuji (2016) stressing the need for school facilities, observed that the physical appearanceand general condition of school physical facilities are the striking basis upon which many parents and friends of any educational institutions may make their initial judgments about the quality of what goes on in the school. The fact is if students have motivation in their schools interior environment, they would be more academically successful (Fielding, 2010). For the East District, the findings indicated that on whole, academic/achievement performance of pupils are not rated high,Pupils do not spent high quality time in school for effective learning, Pupils do not demonstrate high learning interest, Time management, skills and competencies are not achieved, Pupils' tests scores and grade are not encouraging to learning achievements and Learning objectives are not generally achieved. Again, there was agreement among the teachers in the East District that attitude of pupils are key to learning; school structure has positive affect learning and on ground school plants contributes to pupils' learning achievement. This is in line with a report stated by Mudassir and Norsuhaily (2015) that the educational process of development occurs in physical, social, cultural and psychological environment which implies that a proper and adequate environment is very much necessary for a fruitful learning.

On the relationship that exists in the state of dilapidation of schools by teachers' perspective in the three senatorial districts of Kogi State, the results confirmed that school dilapidation across the three senatorial districts in Kogi State was characterized by pupils' attitudes to learning and school structure, negatively affecting learning in Kogi State. Again, across the senatorial districts, there are varying but related opinions on pupils' achievement based on the pupils' attitude to learning and level of school structures affecting learning. This shows that, pupils were influenced by the physical environment around them. According to Mitchell as cited by Adamu (2015) the environment in which you study can have a big effect on how efficient your study time is? Then educators would do well to look closely at their classrooms to understand how they use the environment as a tool in improving instruction and pupils' achievement. In terms of the state of dilapidation of schools in the three senatorial districts of Kogi State, the West, Central and East are the same. However, higher significant correlation exists in East and West senatorial districts in Kogi State which implies that the level of dilapidation of schools in the districts varies to some degrees.

In terms of the relationship that exists in the state of pupils' achievement in schools by teachers' perspective in the three senatorial districts of Kogi State, pupils' achievement in the West, Central and East are the same. However, significant and high correlation was evident in East and West senatorial districts in Kogi State which implies that the level of pupils' achievement in the districts varies. If the claim of Balog (2018) that the physical environment/learning space refers to the 
Journal of Education and Practice

ISSN 2520-467X (online)

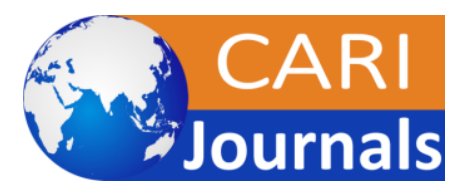

Vol.4, Issue No.4, pp 14 - 42, 2020

www.carijournals.org

physical setting of the learner's environment which should evoke positive responses and hold the interests of those who inhabit it is anything to go by, the State government must address the issue of dilapidation across the districts. This was emphasized by Mudassir and Norsuhaily (2015) who stated that Students of a school with adequate facilities, good teachers and favorable environment perform better than those from schools with fewer facilities, unqualified teachers and unfavorable environment.

In comparing the factor measures of school dilapidation in Kogi State, the Least Significant Difference (LSD) test suggested that there is significant difference in the level of school dilapidation in the East Senatorial District and Central Senatorial District. However, East Senatorial District and West Senatorial District are not significant. This implies that East Senatorial District and West Senatorial District suffer the same faith of school dilapidation over the years in the Kogi State since the associated mean probability values are greater than 0.05 at $5 \%$. Again, based on the results of Duncan Multiple Range Test, the school dilapidation is much more evidence in East and West senatorial district in Kogi State.

In comparing the factor measures of achievement within Kogi State, high learning interest demonstrated by pupils, Pupils' tests scores and grade are encouraging to learning achievements and the school structure positively affect learning. This is in line with a study by Mudassir and Norsuhaily, (2015) which indicated that students from a school with adequate facilities, good teachers and favorable environment perform better than those from schools with fewer facilities, unqualified teachers and less enabling environment. This shows that students have right attitude to learning but affected by the level of decay in the school dilapidation in Kogi State. Again, in testing the significance of the factor measures of pupils' achievement based on teachers' perception in Kogi State, the Least Significant Difference (LSD) test suggestd that there is no significant difference in the pupils' achievement in all the senatorial districts. Measures of pupils' achievement perception of teachers across the districts in the Kogi State are the same since the associated mean probability values are greater than 0.05 at 5\%. In terms of pupils' achievement, the results of Duncan Multiple Range Test suggest that among the measures of achievement of pupils in Kogi school system were highly discouraging given the mean response value within 2.0 (disagreement).

On the relationship between dilapidation of schools and pupils' achievement in Kogi State as perceived by teachers, the findings suggested that the influence of school dilapidation on school achievement has low positive effect and not significant. In terms of the strength of the relationship, the results showed that the influence of school dilapidation has low influence on school achievement in Kogi State. The findings also implied that the relationship between school dilapidation and achievement showed a very low variance in Management Style (MS). Thus, the remaining is due to other factors and residuals. Again, the results revealed a significant low positive relationship between school dilapidation and dependent variable school achievement. In using ANOVA, the result further showed that, there was a linear relationship between the school dilapidation and school achievement in Kogi State, Nigeria. This result is similar to that of Adamu (2015) who examined the impact of

environment on the Performance of Students in public secondary schools in Taraba State, Nigeria and the findings revealed a significant difference in the performances of the two groups 
Journal of Education and Practice

ISSN 2520-467X (online)

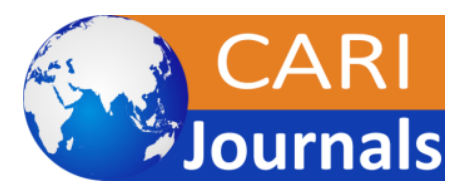

Vol.4, Issue No.4, pp 14 - 42, 2020

www.carijournals.org

(Experimental and Control) implying that a classroom building; class with adequate furniture has positive impact on the performance of students in junior Secondary schools. Finally, in comparing the contribution of each independent variable, a unit increase in the level of school dilapidation will account for $25.3 \%$ decrease in school achievement in Kogi State. The outcome of the result indicates that increase in the school dilapidation will decrease school achievement by $25.3 \%$ in Kogi State. Again, this result is in tandem with a finding by In a study carried out by Hale as cited by Ibitoye (2017), revealed that students in classrooms with large windows, natural lighting and well-designed skylights were found to perform well from $19 \%$ to $25 \%$ better than their peers in classrooms without these feature. This may be why the President of the Nigerian Union of Teachers (NUT), Olukoya as reported in Vanguard (2012) lamented the deteriorated state of schools at local government, state and federal government levels at the Eagle Square in Abuja, regretting the poor condition of the schools and its negative contribution to the performance of pupils and students across the nation. According to him, 'we wish to use this auspicious day to remind the government of Nigeria on all the tiers that our schools are still largely dilapidated and are unsuitable for conducive learning". Olukoya noted that, "Learners do well when they study in a conducive environment. It is a conducive environment that makes a teacher to perform at his optimum". Although, the school dilapidation based on the study does not significantly influence achievement in the state, its effect cannot be down played.

On the test of hypothesis, the null hypothesis was accepted or not rejected. That is, there is no significant relationship between school dilapidation and school achievement. Thus, school dilapidation does not significantly influence school achievement in Kogi State. This finding is in contrast with that carried out by Ezike (2018) who investigated classroom environment and students' academic interest as correlates of achievement of students in selected Public Secondary Schools in Ibadan, Oyo State, Nigeria. The result showed significant relationships between classroom environment and academic achievement, while combined contribution of classroom environment and academic interest was equally significant. However, the result of the test suggested that, when there is any change in factors influencing school dilapidation, it has negative effect on school achievement in Kogi State. Thus, the findings herein, indicated that, poorer achievement was associated with dilapidated school structures. This assertion is supported by a study conducted by Eimuhi and Ogedegbe (2016) on the effect of environmental factors in teaching and learning in primary and secondary schools in Edo state of Nigeria examined environmental factors to determine the outcome of teaching and learning at all times and in all places and concludes that the more enriched the learning environments is, the greater and more widespread are the benefits for academic performance and other outcomes.

During the visits to schools, interviews of teachers revealed that a majority of them seemed to see five (5) out of the nine (9) items which are insufficient desk, large class size, licking class roof, not well lighted classes, Classes with fallen walls as major issues affecting pupils' achievement. They however, did not see Not well painted classroom and Classes with fallen walls as serious factors to consider. Looking at these above claims, it is clear that the opinions of the teachers were well founded as, insufficient desk, not well lighted classes and large class size cannot create room for any meaningful learning. Similarly, a licking class roof when it is raining will definitely inhibit learning. The fact that teachers felt that the class painting mattered less than other factors could be because of the socio-economic reality of the environment in the country, where most houses are 
Journal of Education and Practice

ISSN 2520-467X (online)

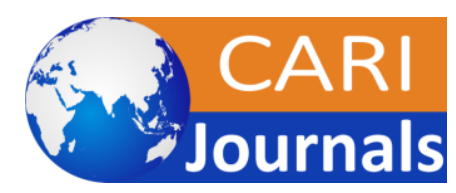

Vol.4, Issue No.4, pp 14 - 42, 2020

www.carijournals.org

not well painted across the State. From the interpretation of the table and discussion in this study, the opinions of the teachers in the course of the interview supported the interpretation of the analysis. No doubt therefore that, if Kogi State government and other stakeholders desire an improvement in the present state of pupils' achievement, they must consider the environment where teaching and learning take place. In this regard, the government of Osun State demolished no fewer than 3,000 dilapidated school buildings out of the 4,000 identified across the 30 local government area were by the state government (Nigeria Newsday, 2013) in the State's bid to ensure quality education.

\section{SUMMARY OF FINDINGS, CONCLUSION AND RECOMMENDATIONS}

\section{Summary of Findings}

From research question one, the results confirmed that school dilapidation across the three Senatorial Districts in Kogi State vary and was characterized generally by Bad/damaged classroom seats, Licking class roof and Insufficient desk in Kogi State.

From research question two, the learning objectives are not generally achieved; on the whole, academic/achievement performance of pupils are not rated high, on ground school plants does not contribute to pupils' learning achievement. In addition, pupils do not spend high quality time in school for effective learningof pupils' achievement. However, there is very strong agreement that Attitude of pupils are key to learning contributed to the pupils' achievement based on teachers' perception.

From research question three in terms of correlation, the state of dilapidation of schools in the three senatorial districts of Kogi State varies to some degrees.

From research question four, in terms of the relationship of pupils' achievement in schools by teachers' perspective in the three Senatorial Districts of Kogi State, the level of pupils' achievement varies.

From research question five, in comparing the factor measures of school dilapidation in Kogi State, school dilapidation is much more evidence in East and West Senatorial District in Kogi State.

From research question six, in comparing the factor measures of achievement within Kogi State, the findings suggested that there is no significant difference in the pupils' achievement in all the Senatorial Districts.

From research question seven, there is a linear relationship between the school dilapidation and school achievement in Kogi State. Thus, school dilapidation across the three Senatorial Districts in Kogi State impact on key to learning and the school structure affects learning in the State. However, the school dilapidation based on the study does not significantly influence achievement in the state.

From the research hypothesis, school dilapidation does not significantly influence school achievement in Kogi state. However, when there is any change in Factors Influencing school dilapidation, it has negative effect on the school achievement in Kogi State.

\section{Conclusion}


Journal of Education and Practice

ISSN 2520-467X (online)

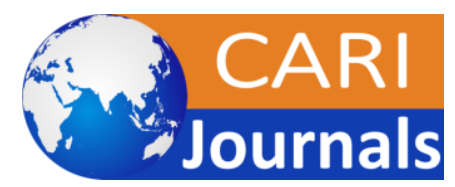

Vol.4, Issue No.4, pp 14 - 42, 2020

www.carijournals.org

Generally, there has been awareness among the public that school dilapidation and learner achievement are key factor in educational administration, management and organization in Nigeria. This study found out that school dilapidation across the three Senatorial Districts in Kogi State were characterized by Bad/damaged classroom seats, Large class size, licking class roof, Insufficient desk, not well painted classroom, Class roofs that are not well ceiled, Bad/damaged classroom seats and Classes with fallen walls contributes to school dilapidation factors in state. These therefore, impact on teaching and learning in primary schools. School Achievement Measures Rank Analysis by District in Kogi State reveal that time management, skills and competencies are not achieved and pupils' tests scores and grade are not encouraging to learning couple with low level of learning interest demonstrated by pupils. In Nigeria, primary education is the education children receive before secondary education and thereafter the tertiary stage to prepare them for useful living within the society. It is said that if the foundation be destroyed, what can the righteous do? It will not be an overstatement to say that nothing can be done about the much talked about fallen standard of education in the country until the decay at the primary level is addressed. If our education must deliver the benefits it holds, then the physical structure of our primary school is a sure site to consider as the primary education offers the springboard for upward movement in the education ladder. The government of Kogi State may consider taking a cue from the State of Osun in response to dilapidated school structure as reflected in this study.

\section{Recommendations}

School dilapidation affect achievement in school system world over, as a result, this study confirmed the negative effect of school dilapidation and pupil's learning in Kogi State. The findings and conclusions lead to the following recommendations:

i. Government should ensure that there is sufficient desk in classrooms, repair or replace of $\mathrm{bad} /$ damaged seats and avoid the use of buildings with licking class roofs.

ii. The relevant government agencies should ensure the provision of good and adequate school plant and recruitment of qualified teachers that could help promote the attitude of pupils for better learning achievement in the state.

iii. School architects, educators and facility planners must take into consideration the impact that the design and materials used for school buildings have on pupils' academic achievement.

iv. There should be a declaration of a state of emergency on school system to salvage and surmount the challenges.

v. The government of Kogi State should identify and develop policy, legal frame work and infrastructural provision to mitigate the level of dilapidation in schools across the state.

\section{REFERENCES}

Abdullahi, N. S. (2019). Kogi State governmentt had embarked on total renovation of dilapidated structures in public schools. Accessed on 26 November, 2020 from https://www.google.com/url?q=https://allnigeriantrend.wordpress.com/kogi-state-govthad-embarked-on-total-renovation-of-dilapidated-structures-in-public-schools-subebchairman/\&sa=U\&ved=2ahUKEwjtg4P9tZ tAhWLiFwKHdRADh4QFjABegQIAhAB\& usg=AOvVaw2iNG6R84E_59VdQAweke1K. 
Journal of Education and Practice

ISSN 2520-467X (online)

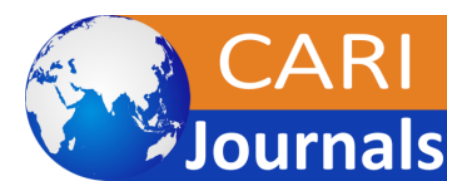

Vol.4, Issue No.4, pp 14 - 42, 2020

www.carijournals.org

Adamu, N. (2015). Impact of learning environment on the performance of students in social studies in junior secondary schools in Taraba State, Nigeria. A thesis submitted to the school of postgraduate studies, Ahmadu Bello University, Zaria.

Balog, N. (2018). Impacts of the learning environment on developer's progress. Accessed on 26 November, 2020 from https://www.codingdojo.com/blog/impacts-of-the-learningnvironment.

Eimuhi, J.O. \& Ogedegbe, B. G. (2016).The effect of environmental factors in teaching and learning in primary and secondary schools in Edo State of Nigeria. Journal of Emerging Trends in Educational Research and Policy Studies (JETERAPS), 7(4), 310-317.

Emmanuel, J. \& Omale, A. (2020). Left in ruins: Public schools' facilities deteriorate in Kogi State as students learn in leaky classrooms. Accessed on 26 November, 2020 from https://www.google.com/url?q=http://saharareporters.com/2020/10/01/left-ruins-publicschools\%25E2\%2580\%2599-facilities-deteriorate-kogi-state-students-learnleaky\&sa=U\&ved=2ahUKEwjtg4P9tZ tAhWLiFwKHdRADh4QFjAEegQIBRAB\&usg =AOvVaw0sWRjHkao07PuLSNqyVL3z.

Ezike, B. U. (2018). Classroom environment and academic interest as correlates of achievement in senior secondary school chemistry in Ibadan South West local government area, Oyo State, Nigeria. Global Journal of Educational Research. 17, 61-71.

Federal Republic of Nigeria (2004). National policy on education (revised edition). Lagos: NERDC.

Fielding, R. D. (2010).Primary prevention during school transitions: Social support and environmental structure. American Journal of Community Psychology, 4 (10), 277-290.

Gilavand, A. (2016).Investigating the impact of environmental factors on learning and academic achievement of elementary students: Review. International Journal of Medical Research \& Health Sciences: PP.360-369. Accessed on 26 November, 2019 from https://www.researchgate.net/publication/306960243_Investigating_the_Impact_of_Envir onmental_Fac

tors_on_Learning_and_Academic_Achievement_of_Elementary_Students_Review.

HomeLatest News (2018). Stakeholders decry dilapidation of schools, call for FG's urgent intervention. Accessed on 26 November, 2020 from https://www.google.com/url?q=https://www.independent.ng/stakeholders-decrydilapidation-of-schools-call-for-fgs-urgentintervention/\&sa=U\&ved=2ahUKEwjTu7OuvZ tAhWCiFwKHU1iA08QFjACegQIBhA B\&usg=AOvVaw2yMZ6kQRLAEoDJKHVZYDxt.

Ibitoye, O. M. (2017). Impact of learning environment on junior secondary school students' performance in civic education in Kogi State, Nigeria . An M.Ed. dissertation submitted to the school of postgraduate studies, Ahmadu Bello University, Zaria.

Mondal, A. (2012).Important factors that may affect the learning process. Accessed on 26 November, 2019 from http://www.yourarticlelibrary.com/learning/7-important-factorsthat-may-affect-the-learning- process/6064. 
Journal of Education and Practice

ISSN 2520-467X (online)

Vol.4, Issue No.4, pp 14 - 42, 2020

www.carijournals.org

Mudassir, I.U. \& Norsuhaily, A. (2015). The influence of school environment on academic performance of secondary school students in Kuala Terengganu, Malaysia. Proceedings of ICIC2015 - International Conference on Empowering Islamic Civilization in the 21st Century 6-7 September. Accessed on 26 November, 2019 fromhttps://pdfs.semanticscholar.org/924e/7c8b4c9744c4a66f26366a9c341ece63b038.pd f.

Naija News (2013, January 31). Poor school standard will soon be history in Kogi State. Accessed on 8 February, 2020 from news.naij.com/22014.html.

Nigeria Newsday (2013, February, 1). Osun State demolish 3,000 dilapidated schools. Nigeria Newsday. Accessed on 17 December, 2019 from nigeriannewsday.com $>$ Home $>$ New and Commerntary $>$ Education/Technology.

Nwagu, N. A. (2010). Primary school administration. Ibadan: Macmillan Publishing Company.

Oduwaye, R. O. (2011). Learning environment and school management. Lagos: Scholastic and Allied Production Ltd.

Okoza, J.. Aluede, O. \& Akpaida, J.E.A. (2012). Secondary school students' perception of environmental variable influencing academic performance in Edo State, Nigeria. Accessed on 16 December, 2019 from http://bangladeshsociology.org/BEJS 209(2).

Osuji, J. N. (2016). Impact of school facilities on students' academic performances in public secondary schools in Giwa and Zaria education zones, Kaduna State, Nigeria. A dissertation submitted to the school of postgraduate studies, Ahmadu Bello University, Zaria.

Shamaki, T. A. (2015). Influence of learning environment on students' academic achievement in mathematics: A case study of some selected secondary schools in Yobe State, Nigeria. Journal of Education and Practice, 6 (34), 40-44. UNESCO (2012). A place to learn: Lessons from research on learning environments. Accessed on 26 November, 2020 from http://uis.unesco.org/sites/default/files/documents/a-place-to-learn-lessons-fromresearch-on-learning-environments-2012-en.pdf.

Vanguard (2012, October 5). Teachers raise alarm over dilapidated condition of schools. Vanguard. Accessed on 12 November, 2013 from www.vanguardngr.com/2012/10/. 